\title{
多極着磁磁石を用いた新回転センサ
}

\author{
正員 加藤 哲男 (大同工業大学) \\ 正員 草加 勝司 (大同工業大学) \\ 学生員鈴木 智也 (大同工業大学)
}

\section{New Rotation Sensor by Magnetized Multipolar Magnet}

Tetsuo Kato, Member, Katsusi Kusaka, Member, Tomoya Suzuki, Student Member

(Daido Institute of Technology)

キーワード：多極着磁磁石，回転センサ，磁石回転

\section{1.はじめに}

単極誘導の現象(1)(2)から思いついて，その磁石を2極 とする双極誘導の実験を行った (3)ところ、これから，先に 回転センサとしての新しい方法が見出されるに至った (4)(5)。 これは 2 極に着磁された回転する円盤状磁石に対向させて， 裹側に軟賀磁性材料を張り合わせた円盤状の金属尊体を圈 くと，その金属導体の外周部と中心部之の間に正弦波状の 交流電任が誘起されるという現象である。この交流電圧の 大きさは磁石の回転数に比例し，また，その周波数は回転 数と一致している。これにより，新しく，極めて棈造簡単 な回転数検出のセンサが提供されることになるものと考え られる。しかしながら，この方法について実用化を図って ゆくためにはさらに磁石を多橝にすることができるである うかとか，磁石と軟質磁性材料の閔隔が広くなったらどう なるであろうかなどの構造上の問題について，確かめてお くことが必要であると考えられた。それらについて検討を 行ったので，その結果について報告する。

\section{2. 実験装置および方法}

試作した春娩装置の概要を図 1 に示す。磁石には中心部 を空洞にした円環状のNdFeBボンド磁石を用いた。これ を右側の図に見られるように8極に着磁した。外周および 内周の寸法は图に示した通りで，愿さは $8 \mathrm{~mm}$ となっい る。磁石の中心部を除外したのは，互いに瀿り合うNS 磁 極間の平均距離を大きくとるように考えたことによる。綉 起電圧は直径の 2 乗に比例する(4) (5)ので，このようにし ても電圧の大きさに対する影響は比較的少ないということ ができる。金属導体(銅)蛙径 $38 \mathrm{~mm}$ ，厚さ $2 \mathrm{~mm}$ の円盤 で，その裏側に張り合わせた軟質磁性材料(電磁純鉄)は㨁 径 $38 \mathrm{~mm}$ ，愿さ $5 \mathrm{~mm}$ なっている。その両者は電気的に 絶縁されている。なお，磁石と電磁純鉄の間隔忏可変とし
た。これによって，磁石を銅板を介して中心軸の周りに回 転させ，銅板外周部と中心部との間に誘起する電在を測定 する。

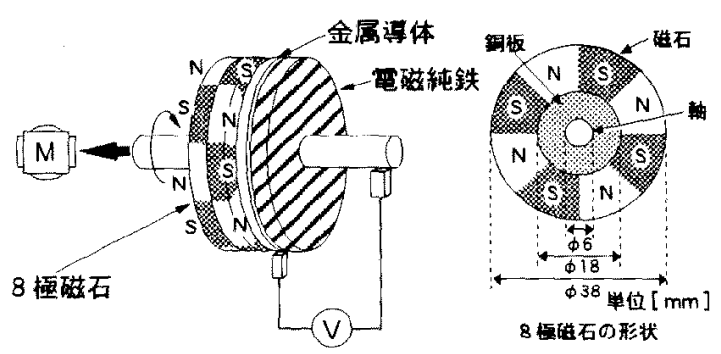

図 1 奏験装置の概要

Fig. 1 Structure of experimental apparatus.

\section{3. 赛験結果および考察}

はじめに，磁石と電磁純鉄との間隔を $3 \mathrm{~mm}$ として測定 したときの電王波形の例を図 2 に示す。これ磁石の回転 数を28.0rpsとした場合における例であるが，先の2極に おける場合 (4) (5) と同様にきれいな正弦波状となっている。 また，この周波数忖完全に回転数の 4 倍と一致している。

次に, 図 3 は磁石と電磁純鉄との間隔を $3 \mathrm{~mm}$ から約 $12 \mathrm{~mm}$ まで変化させたとさの回転数による誘起電圧（最大 值）の変化について測定した結果を示す。どの間隔におい ても回転数の增加に従って誘起電圧は道楾的に增加し, 再 者は完全に比例関係になっていることが認められる。

図4はこれを磁石と電磁純鉄との間隔の関係としてまと め直した結果を示す。この場合に磁極間の平均距離は約 $11.5 \mathrm{~mm}$ となっているが, 両者の間隔がほほ磁極間の平均 距離の近くになるまで電圧の検出が可能となっていること が知られる。この結果から計算すると，この寸法の磁石に 


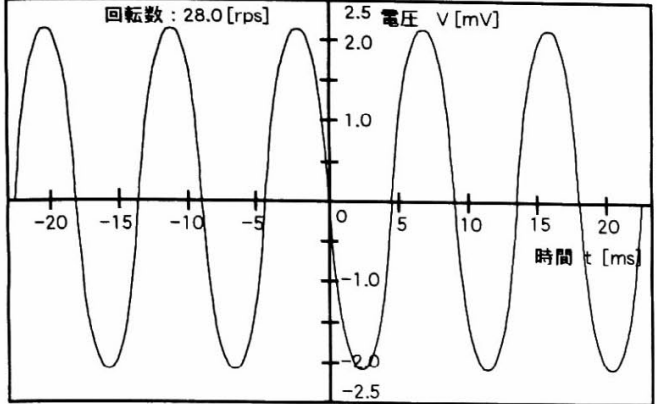

図 2 電圧波形例

Fig. 2 Example of voltage wave form.

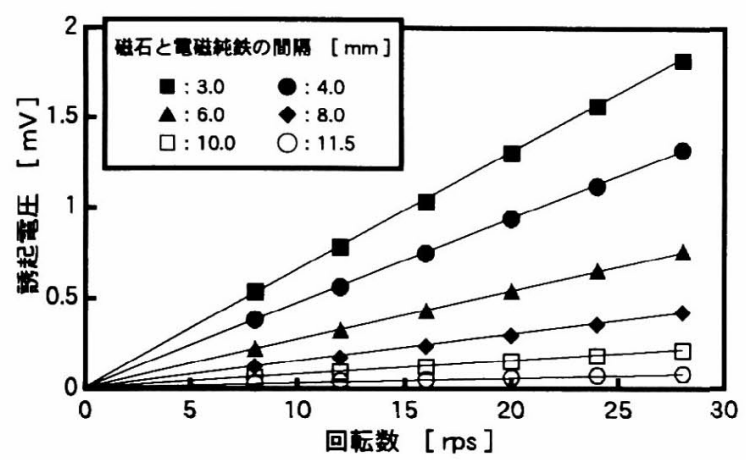

図 3 回転数と誘起電圧の関係

Fig. 3 Relation between the rotation speed and the induced voltage.

おいて，36極以上まで磁極を増加させても十分電圧の検出 が可能であると考えられる。

なお，図 5 のような電子回路を試作して電圧の検出端に 付加することにより, 誘起電圧の周波数のデジタル表示が 磁石の回転数の 4 倍に一致することを確認している。

本研究にご支援を頂いた大同特殊鋼株式会社技術開発研 究所 水野正志研究所長ならびに遠藤敏夫 F A 研究室長に 深く感謝申し上げる。また，ご協力を頂いた大同工業大学 電気工学科 尾畑智光氏に厚く謝意を表する。

(平成 9 年 2 月 5 日受付, 同 9 年 3 月 7 日再受付)

\section{文 献}

1) 舟橋憲治：電気磁気学, p.146（東京電気大学出版局, 1962)

2) 加藤哲男, 窪野岳, 鈴木智也：電子材料, 35 (1996) 6, 80

3）加藤哲男：電子材料, 35 (1996) 9, 109

4) 加藤哲男, 窪野岳, 水野正志 : 電気学会論文誌, E116 (1996) , 240

5) TetsuoKato, TakeshiKubono,Masashi Mizuno: Rev.Sci.Instr, 67 (1996) , 4017

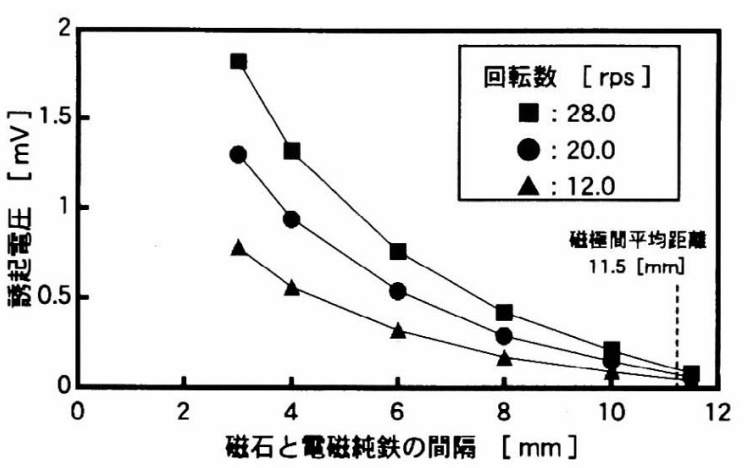

図 4 磁石之電磁純鉄の間隔と誘起電圧の関係 Fig. 4 Relation between the distance from magnet to magnetic soft iron and the induced voltage.

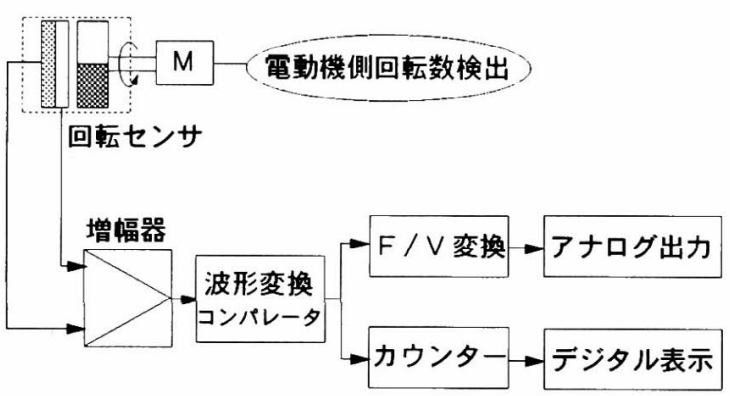

図 5 周波数検出電子回路

Fig. 5 Electronic circuit for frequency detection.

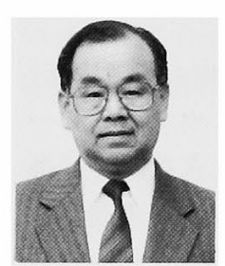

\section{加 藤 哲 男 (正員)}

昭和 2 年 3 月 15 日生。26年東京工業大 学 (電気コース) 卒業。大同製鋼（現大 同特殊鋼）入社。57年中央研究所所長, 61 年常務取楴役。平成元年大同工業大学 教授。工学博士。鉄鋼協会西山記念賞, 計測自動制御学会論文賞，金属学会技術開発賞，同技術賞， 同谷川ハリス賞，科学技術庁長官賞受賞。

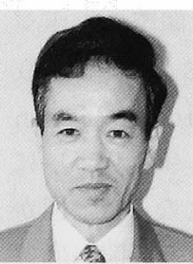

\section{草 加捗 司 (正)}

昭和 13年10月 6 日生。39年名古屋大学 理学部物理学科卒業。大同製鋼（現大同 特殊鋼）入社。平成 2 年研究開発本部新 素材研究所長, 5 年技術開発研究所主席 研究員。9 年大同工業大学教授。工学博 士。粉体粉末冶金協会技術開発賞, 日本金属学会技術賞, 科学技術庁長官賞受賞。

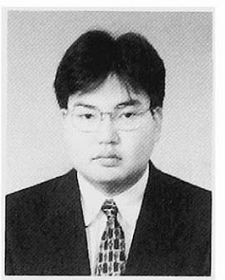

\section{鈴 木 智 也 (学生員)}

昭和 48 年 8 月 28 日生。平成 8 年大同工 業大学卒業。同大同工業大学大学院電気 電子工学専攻入学。現在に至る。 